\section{Det som skal læres, må sies - og sies godt}

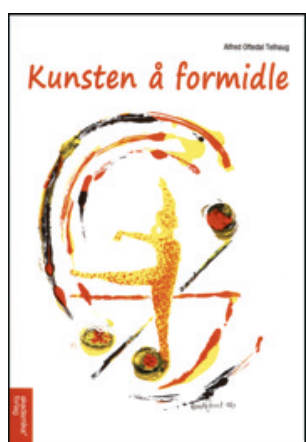

Alfred Oftedal Telhaug

109 s, ill. Trondheim: Akademika forlag, 2013. Pris NOK 220

ISBN 978-82-321-0191-7

Kunnskapsformidling har historisk sett vært den mest sentrale oppgaven for lærere i skolen. Kunnskap skal overføres fra lærerne til elevene. En slik formidlingspedagogikk ble etter siste verdenskrig, særlig fra rundt 1970, gradvis erstattet av reformpedagogikken, som la mindre vekt på lærernes rolle som kunnskapsformidlere og mer vekt på deres rolle som tilretteleggere og veiledere for elevenes egen læring. Elevene skulle ikke lenger belæres eller bli styrt av læreren, men selv finne frem til kunnskapen. Hensikten var bl.a. å fremme samarbeid, mer relevant kunnskap og gode holdninger. Puggeskolen skulle bekjempes.

Også norske universiteter ble preget av reformpedagogikken. Tradisjonelle kateterforelesninger av professorer kom i miskreditt nå var det studentaktiviserende undervisning som var tingen. På medisin ble problembasert læring, der studentene skulle lære å innhente kunnskap i grupper, introdusert i nye studieplaner, og antall forelesninger ble redusert. Effekten av denne omleggingen er usikker og lite dokumentert.

Alfred Oftedal Telhaug (f. 1934), professor emeritus i Trondheim og en nestor i norsk pedagogikk, har vært en motstemme i denne utviklingen. Han er en skrivefør praktiker og akademiker med et klart budskap: Kunnskapsformidling må få en større plass i norsk skole og høyere utdanning. Heldigvis synes de skolepolitiske motsetninger fra få tiår tilbake å ha blitt mindre, og det synes nå å være bred enighet om at skolens suksess er avhengig av lærerne og deres evner og muligheter til god kunnskapsformidling.

Telhaug har skrevet mye og godt om kunnskapsformidling. I denne lille boken, nærmest et hefte, gjennomgår han utviklingen av norsk pedagogikk de siste mannsaldre - sett fra en kritikers ståsted. Læring er hardt arbeid - for både lærer og elev. Dyktige lærere som kan sitt fag, og som er i stand til å formidle kunnskap på en god måte, er pedagogikk på sitt beste. Gode forelesere inspirerer. Dårlige forelesninger er dårlig pedagogikk, men sier lite om forelesningens potensial som pedagogisk metode.

Boken anbefales for lærere på alle nivåer, også for lærere ved våre medisinske fakulteter, som en kort innføring i de teoretiske og ideologiske strømningene som har ligget til grunn for utviklingen i norsk skole og høyere utdanning. Forfatteren gir også tips og inspirasjon til dem som ønsker å forbedre sin egen formidling av kunnskap, både i skrift og tale. Begge deler krever et visst talent, mye trening og mange forberedelser. Jeg anbefaler ikke minst boken til dem som nå leder arbeidet med å revidere studieplanene i medisin. Her er det mye å hente.

\section{Petter Gjersvik}

Institutt for klinisk medisin

Det medisinske fakultet

Universitetet i Oslo

\section{Kunnskapsbasert guide til alternativ medisin}

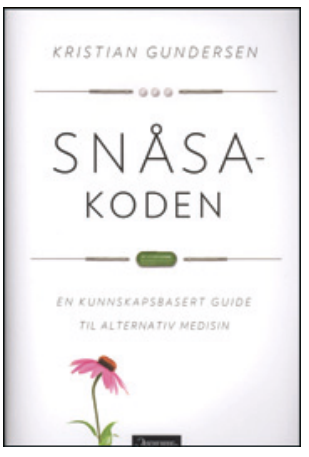

Kristian Gundersen

\section{Snåsakoden}

En kunnskapsbasert guide til alternativ medisin. 299 s, tab, ill. Oslo: Aschehoug, 2013.

Pris NOK 369

ISBN 978-82-03-29388-7

Målgruppen er enhver som er interessert $i$ alternativ medisin. Boken fungerer bra som en lærebok for de som ønsker bedre kunnskap innen dette feltet, sett med vitenskapens briller.

Boken er lettlest og velskrevet med enkelte illustrasjoner og tabeller. Gundersen forteller om hvorfor det er vanskelig å gi en entydig definisjon av alternativ medisin. Deretter forklarer han hvordan tradisjonell vestlig medisin har utviklet seg til å hjelpe stadig flere ved hjelp av vitenskap. Han foreller videre om hvordan man med anekdoter, kirsebærplukking, påstander om gamle tradisjoner etc. kan gi inntrykk av at alternative metoder virker. Det skal her sies at vi alle er utsatt for å tenke feil, men kunnskap om hvordan vi kan tenke «riktig» og «feil» reduserer risikoen for å tenke feil.

Etter å ha presentert ulike tankeganger kommer en gjennomgang av ulike alternativmedisinske terapier. Først presenterer forfatteren de mest kjente formene, som homøopati, akupunktur, kvantemedisin og plantemedisin. Det alternativmedisinske feltet er så vidt at mange former må samordnes i hovedfelt som manipulasjonsterapi (naprapati, kraniosakralterapi etc.), pseudovitenskapelige retninger (lysakupunktur, tankefeltterapi) og «dietter, lukter og vann» (aromaterapi, Bachs blomstermedisin).

Det gis, i den grad det finnes, informasjon om behandlingens grunnlegger, tankegang og vitenskapelige belegg. Hva gjelder akupunktur, informeres det om at det finnes et tynt grunnlag for smertestillende effekt, men at det er uavhengig av stikksted/dybde. Kiropraktikk har noe effekt når det gjelder rygg og nakkesmerter. Utover dette er det begrenset dokumentasjon for positiv effekt av de ulike terapiene.

Boken inneholder også kapitler som omtaler uavklarte sykdommer som el-overfølsomhet og kronisk utmattelsessyndrom (ME), hvordan behandlere godkjennes innen det offentlige helsevesen og det alternative.

Personlig savner jeg en grundigere gjennomgang av alternativmedisinske skyggesider, som antivitenskapelig holdning, deriblant uttalt vaksinemotstand, som finnes i enkelte miljøer. Det kan dog argumenteres for at det er utenfor temaet som man tar opp. Gundersen gir en god, kunnskapsbasert guide til den alternative medisinen, og da de fleste leger treffer pasienter som også får behandling utenfor det skolemedisinske systemet, vil boken være nyttig for de fleste av oss.

\section{Daniel Øyan}

Barneavdelingen

Drammen sykehus

Oppgitte interessekonflikter: Anmelder har engasjert seg som motstander av alternativ medisin, blant annet i Legeforeningens etiske råd. 